\title{
Drug Carriers Based on Graphene Oxide and Hydrogel: Opportunities and Challenges in Infection Control Tested by Amoxicillin Release
}

\author{
Anna Trusek 1,*(D) and Edward Kijak ${ }^{2, *(D)}$ \\ 1 Group of Micro, Nano and Bioprocess Engineering, Department of Chemistry, Wroclaw University of Science \\ and Technology, Wybrzeże Wyspiańskiego 27, 50-370 Wroclaw, Poland \\ 2 Department of Dental Prosthetics, Wroclaw Medical University, Krakowska 26, 50-425 Wroclaw, Poland \\ * Correspondence: anna.trusek@pwr.edu.pl (A.T.); edward.kijak@umed.wroc.pl (E.K.)
}

check for updates

Citation: Trusek, A.; Kijak, E. Drug Carriers Based on Graphene Oxide and Hydrogel: Opportunities and Challenges in Infection Control Tested by Amoxicillin Release. Materials 2021, 14, 3182. https:// doi.org/10.3390/ma14123182

Academic Editor: Xiaozhong Qu

Received: 7 May 2021

Accepted: 7 June 2021

Published: 9 June 2021

Publisher's Note: MDPI stays neutral with regard to jurisdictional claims in published maps and institutional affiliations.

Copyright: (c) 2021 by the authors. Licensee MDPI, Basel, Switzerland. This article is an open access article distributed under the terms and conditions of the Creative Commons Attribution (CC BY) license (https:/ / creativecommons.org/licenses/by/ $4.0 /)$.

\begin{abstract}
Graphene oxide (GO) was proposed as an efficient carrier of antibiotics. The model drug, amoxicillin (AMOX), was attached to GO using a peptide linker (Leu-Leu-Gly). GO-AMOX was dispersed in a hydrogel to which the enzyme responsible for releasing AMOX from GO was also added. The drug molecules were released by enzymatic hydrolysis of the peptide bond in the linker. As the selected enzyme, bromelain, a plant enzyme, was used. The antibacterial nature of the carrier was determined by its ability to inhibit the growth of the Enterococcus faecalis strain, which is one of the bacterial species responsible for periodontal and root canal diseases. The prepared carrier contained only biocompatible substances, and the confirmation of its lack of cytotoxicity was verified based on the mouse fibrosarcoma cell line WEHI 164. The proposed type of preparation, as a universal carrier of many different antibiotic molecules, can be considered as a suitable solution in the treatment of inflammation in dentistry.
\end{abstract}

Keywords: amoxicillin; bromelain; chemical activation of graphene oxide; enzymatic drug release; antibacterial carrier; Enterococcus faecalis; periodontal and endodontic diseases

\section{Introduction}

The successful design of a drug carrier requires addressing many issues. Firstly, it is connected with a preparation of an efficient nanocarrier with optimized drug-loading capacity. The second issue is confirming or improving the carrier biocompatibility and elimination of its possible toxicity. Finally, a system able to release drugs in a controllable way with optimized dosage at a specific site required for successful therapy should be designed [1].

Graphene is a flat structure made up of carbon atoms joined together in hexagons. A theoretical description of graphene was developed as early as 1947 in a paper by Wallace [2], but the substance itself it was not produced until 2004 [3,4]. Since then, work on graphene has accelerated-both from a pure research perspective and in the search for ever better methods of producing this material. Graphene, in addtion to a large surface area, has superior mechanical, electrical, and thermal properties. Additionally, graphene can be chemical modified to produce graphene oxide (GO) and reduced graphene oxide (rGO). The presence of oxygen moieties plays a significant role in antimicrobial activity $[5,6]$. Additionally, the reaction of epoxy, hydroxyl, and carboxyl groups of GO with bacteria's biomolecules can influence their cell growth and metabolic system adversely [7].

GO is also being investigated for its use as a drug carrier mainly to deliver anticancer drugs with the most commonly used agents doxorubicin and camptothecin [8], and antibodies for the selective killing of cancer cells. GO drug loading can be applied during chemotherapy and photo-thermal treatment as alone release method and in one system simultaneously $[9,10]$. Drugs are attached both by physical means (adsorption) and by 
using reactive graphene's oxide groups [11-13]. Despite GO's antibacterial properties, it has not been tested as a carrier for antibacterial drugs, including antibiotics.

Dental caries, periodontal and endodontic diseases have a close relationship with microbes. Oral microbial colonization exists in a balance in oral microenvironment. The bacterial microflora is usually composed of many species, most often of pathogenic nature. The literature on the subject is quite divergent concerning the most common bacterial cultures. The participation of individual species is strictly dependent on the primary site of infection and the therapeutic measures taken.

The first studies identified Gram-positive facultative anaerobes such as Enterococcus faecalis and Streptococcus spp. [14-17]. As shown by Rocas et al. E. faecalis is more associated with asymptomatic cases of primary endodontic infections than with symptomatic ones, and E. faecalis was found in cases of endodontic treatment failure. This bacteria was detected in 20 of 30 cases of persistent endodontic infections associated with root-filled teeth [18].

Using molecular-based detection, it was found that Gram-negative anaerobes, including Fusobacterium nucleatum, Treponema denticola and Tannerella forsythia, also can be responsible for periodontal disease $[19,20]$. Gram-negative bacteria, in particular, F. nucleatum elicited an enhanced pro-inflammatory response in macrophages, inhibited osteogenic differentiation and reduced cell viability [21].

Another study demonstrated that Prevotella intermedia was the most prevalent species of the colonies in periodontal pockets, whereas Porphyromonas gingivalis and P. intermedia were the more prevalent in root canals. Isolates of $P$. gingivalis and P. intermedia were simultaneously identified in root canals and periodontal pockets. Eighteen per cent of teeth exhibited the simultaneous colonization by $P$. gingivalis, Tannerella forsythia, and Porphyromonas endodontalis in the pulp and periodontal microenvironments [22]. The crucial role in primary endodontic infection of Prevotella nigrescens is also shown in the paper of Martinho et al. [23]. This strain was found in 57\% of infections.

Such a diverse and often unknown bacterial flora requires a universal solution. Inter alia the antimicrobial properties of GO against dental pathogens were tested [24,25]. He et al. [25] used three typical bacteria of dental caries, periodontal, and periapical diseases, S. mutans, P. gingivalis and F. nucleatum, to evaluate the antibacterial activity of GO nanosheets in different concentrations $(20,40$, and $80 \mu \mathrm{g} / \mathrm{mL})$. The growth of $P$. gingivalis and F. nucleatum was already wholly stopped at a concentration of GO $40 \mu \mathrm{g} / \mathrm{mL}$. S. mutans was the most resistant to GO inhibition; however, at a concentration of $80 \mu \mathrm{g} / \mathrm{mL}$, it was already significantly reduced. Transmission electron microscopy (TEM) images revealed that the cell wall and membrane of tested bacteria lost their integrity, and the intracellular contents leaked out after GO treatment. Not rarely GO antibacterial activity was checked in complex with metals and metal oxides [26-30].

This study aimed to recognize the GO potential as a drug carrier in the treatment of inflammation in dentistry. In the paper [31], we described the efficient, utterly innovative method of the anticancer drug (doxorubicin) to GO binding via a peptide linker. A technique for covalent binding of antibiotic molecules has been developed analogously. A model drug, amoxycillin (AMOX) will be used, and as a plant-derived enzyme, bromelain (BROM) as the releasing enzyme. The antibacterial properties of the carrier will be confirmed on an E. faecalis strain. It is one of the bacterial species responsible for periodontal and root canal diseases.

AMOX is a semi-synthetic $\beta$-lactam antibiotic with bactericidal activity, belonging to the aminopenicillin group (Figure 1). AMO is a broad-spectrum antibiotic. It acts on both Gram-positive (such as Enterococcus faecalis and Streptococcus spp.) and Gram-negative bacteria (such as Prevotella spp. and Fusobacterium spp.); aerobes and anaerobes. It is used to treat many infections, including dental infections. AMOX is the first-choice antibiotic for endodontic infections in both European and Asian countries [32]. 


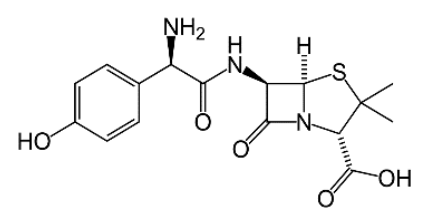

Figure 1. The structure of amoxycillin (AMOX).

BROM is a cysteine endopeptidase with broad specificity for cleavage of proteins obtained from a stem or fruit of Ananas comosus.

\section{Materials and Methods}

\subsection{Materials}

The following reagents: alginic acid sodium salt, Cat. No.180947; N,N'-dicyclohexylcarbodiimide (DCC), Cat. No. D80002; divinyl sulfone, Cat. No. V3700; amoxicillin (AMOX), Cat. No. A8523; ethanolamine, Cat. No. 411000; Gly-Gly-Leu, Cat. No. G9503; N-Hhydroxysulfosuccinimide sodium salt (sulfo-NHS), Cat. No. 56485; bromelain (BROM) from pineapple stem, Cat. No. B4882; artificial saliva, Cat. No. SAE0149; 4-morpholineethanesulfonic acid, Cat. No. M3671 were from Sigma (St. Louis, MO, USA). Graphene oxide (flakes size $<20 \mathrm{~m}$ ) from Advanced Graphene Products (Zielona Gora, Poland), cell line WEHI 164 from American Type Culture Collection (Rockville, MD, USA); Enterobacter faecalis PCM1861 were purchased in Polish Collection of Microorganisms PCMPAN (Wroclaw, Poland).

\subsection{GO-AMOX Complex Preparation}

GO with the peptide linker (Gly-Gly-Leu) was prepared according to the scheme described previously [31,33]. Divinyl sulfone is a known activator of hydroxyl groups in the literature [34,35]. Before AMOX attachment, the carboxyl groups of the linker were activated with DCC, an efficient activator of carboxyl groups [36,37].

The measurements of AMOX concentration were made in solutions before and after drug attachment and also in the first wash solution using high-performance liquid chromatography (HPLC) on a Waters ${ }^{\mathrm{TM}}$ LC Module I plus equipped with a XTerra RP18 column (250 $\mathrm{mm} \times 4.6 \mathrm{~mm}$, particle size $5 \mathrm{~m}$, Waters, Milford, MA, USA) and detection UV at $274 \mathrm{~nm}$. As a mobile phase $0.05 \mathrm{M}$ potassium phosphate, $\mathrm{pH} 5.0$ (the $\mathrm{pH}$ adjusted to 5.0 by using potassium hydroxide) was used. The AMOX concentration was calculated according to a standard curve prepared each time before the series of measurements. Solutions with AMOX concentrations of 4, 20,60, 180, $360 \mathrm{mg} / \mathrm{L}$ were used as standards.

AMOX loading was visualized by FI-IR spectra (FT-IR Nicolet iS50, Thermo Scientific, Waltham, MA, USA) in the region of $400-4000 \mathrm{~cm}^{-1}$. Flakes size distribution before and after drug attachment was monitored using a particle analyser (Sald 2300, Shimadzu, Kyoto, Japan).

\subsection{GO-AMOX Encapsulation in Hydrogel}

The capsules were prepared of $1.8 \%(w / v)$ sodium alginate in $0.1 \mathrm{M}$ MES buffer ( $\mathrm{pH}$ 6.6). The mixture of GO flakes with attached AMOX molecules and sodium alginate solution with BROM at the concentration $0.2 \mathrm{mg} / \mathrm{mL}$ was dropped into a crosslinking bath consisting of $8 \%(w / v)$ sodium chloride solution in $0.1 \mathrm{M}$ MES buffer ( $\mathrm{pH}$ 6.6). In order to avoid protein diffusion during capsule formation, the crosslinking bath also contained $\mathrm{BROM}$ at the concentration $0.2 \mathrm{mg} / \mathrm{mL}$.

As it was presented before [38], capsules containing GO flakes were stable when the ratio of GO flakes to alginate did not exceed 1.46:1 m/v [mg/mL]. When a larger mass of flakes was used, the capsules disintegrated after about $1-2 \mathrm{~h}$. Thus, the prepared capsules were prepared at the ratio of GO flakes to alginate solution 1.12:1 [mg/mL].

The instilled mixture to crosslinked bath solution volume ratio was $1: 1.5$. The crosslinked bath solution was stirred at 230 RPM. The capsules were crosslinked at $6{ }^{\circ} \mathrm{C}$ for $24 \mathrm{~h}$. Then they were washed twice with 0.1 M MES buffer ( $\mathrm{pH}$ 6.6) and stored at $6^{\circ} \mathrm{C}$ in this buffer. 


\subsection{Physical Stability of GO-AMOX Alginate Capsules}

The stability of the capsules was determined based on the change of their diameter after incubation in a given solution. The alginate capsules loaded with GO flakes were prepared with a $1.8 \%(w / v)$ sodium alginate in a $0.1 \mathrm{M}$ MES buffer $(\mathrm{pH}$ 6.6). The ratio of GO flakes to alginate solution was 1.12:1 [mg/mL]. GO flakes were evenly dispersed into solution using ultrasound (power $320 \mathrm{~W}$, frequency $35 \mathrm{kHz}$, time $30 \mathrm{~min}$; Sonorex RK $100 \mathrm{H}$, Bandelin, Germany).

For measuring the capsules diameter, the capsules photos and computer program, Jens Rüdigs Makroaufma $\beta$-programm 0.9.2 (Freiburg, Germany), were used. In each tested solution, 50 capsules having the same initial size were incubated in plastic tubes. Ten capsules as a representative sample used to take photos using a Nikon D750 camera (Chiyoda, Japan). The capsules' photos were taken every two days by 30 days. The stability of the capsules was checked in 0.1 M MES buffer ( $\mathrm{pH}$ 6.6), in artificial saliva ( $\mathrm{pH}$ 6.8) and demineralised water ( $\mathrm{pH}$ 6.8) in $37^{\circ} \mathrm{C}$.

\subsection{Enzymatic Hydrolysis-Antimicrobial Properties of GO-AMOX Alginate Capsules}

GO-AMOX complex (1 mg) was suspended in $2 \mathrm{~mL}$ of $1.8 \%(w / v)$ sodium alginate in 0.1 M MES buffer ( $\mathrm{pH}$ 6.6) with BROM at concentration in the range of $0.04-0.4 \mathrm{mg} / \mathrm{mL}$. The mixture of GO-AMOX and BROM solution was dropped into a crosslinking bath- $8 \%(w / v)$ sodium chloride solution in 0.1 M MES buffer ( $\mathrm{pH}$ 6.6). To avoid protein diffusion during capsule formation, the crosslinking bath contained BROM at the same concentration as the instilled mixture. The crosslinked bath solution was stirred at $230 \mathrm{RPM}$. The capsules were crosslinked at $4{ }^{\circ} \mathrm{C}$ for $24 \mathrm{~h}$. Then they were washed twice with $0.1 \mathrm{M}$ MES buffer ( $\mathrm{pH}$ 6.6) and the release of AMOX was monitored by $24 \mathrm{~h}$ using HPLC. AMOX concentration was determined according the method described in the Section 2.2.

Figure 2 shows the scheme of described drug carrier preparation.

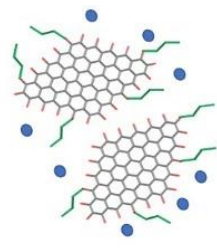

GO-PEPTIDE + AMOX

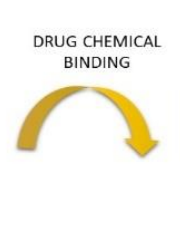

GO-PEPTIDE-AMOX + BROM + SOL

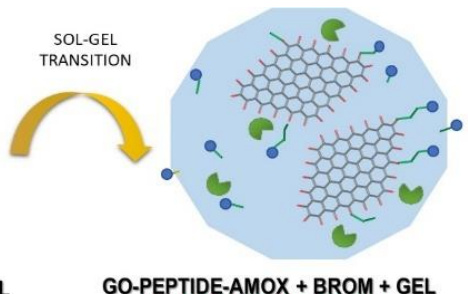

HYDROLYSIS+DIFFUSION

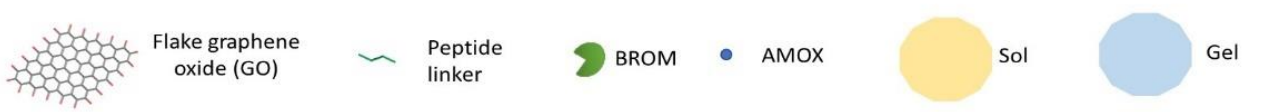

Figure 2. The scheme of preparing a drug carrier based on the covalent attachment of drug molecules and their enzymatic release and diffusion.

The antibacterial properties of the carrier were tested in a reductive culture of E.faecalis was performed on sterile nutrient agar plates. The plates (in 2 replicates) were lined with alginate capsules containing GO-AMOX $\left(1: 2 \mathrm{mg} \mathrm{GO} / \mathrm{mL}_{\text {Alginate }}, \mathrm{m}_{\mathrm{AMOX}} / \mathrm{m}_{\mathrm{GO}}=0.18\right)$ and $\operatorname{BROM}(0.2 \mathrm{mg} / \mathrm{mL})$ and alginate capsules containing dissolved AMOX at concentration $0.1 \mathrm{mg} / \mathrm{mL}_{\text {Alginate }}$.

\subsection{Cytotoxic Effects of Prepared Drug Carriers}

Cytotoxic effects of an AMOX, GO, GO-AMOX complex, and GO-AMOX + BROM solution on the cell line of mice fibrosarcoma WEHI 164 were observed using propidium iodide $[39,40]$. Cells cultivation and viability were performed under conditions described previously [31]. 


\section{Results}

\subsection{GO Flakes Characteristic}

The preparation of GO used consists of about $61.79 \%$ carbon, $37.78 \%$ oxygen. It contains carbonyl, carboxyl, hydroxyl and epoxy groups [41], what was confirmed by FT-IR images (Figure 3). The flakes size was in the range of 1-18 $\mu \mathrm{m}$ with a dominant size in the range 3-11 $\mu \mathrm{m}$ (Figure 4).

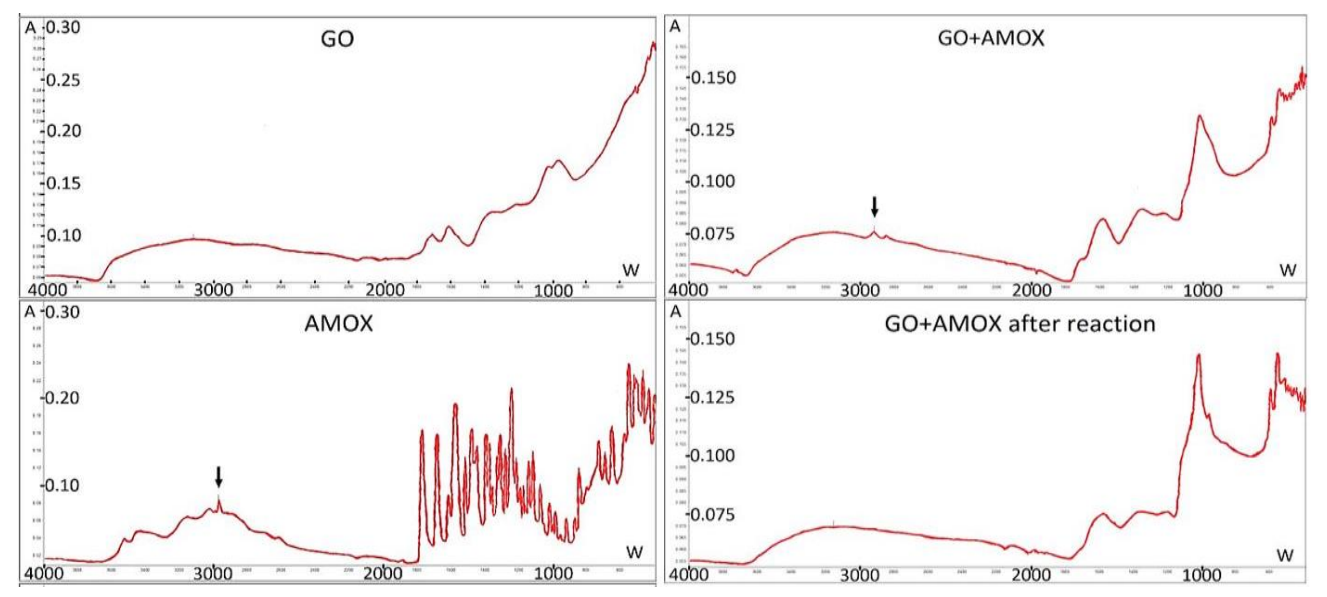

Figure 3. FT-IR spectra of AMOX, GO, GO with AMOX attached, and GO-AMOX after enzymatic reaction $\left(C_{E}=0.2 \mathrm{mg} / \mathrm{mL}, 72 \mathrm{~h}\right)$. A-absorbance, $\mathrm{W}$-wavenumbers $\left[\mathrm{cm}^{-1}\right]$.

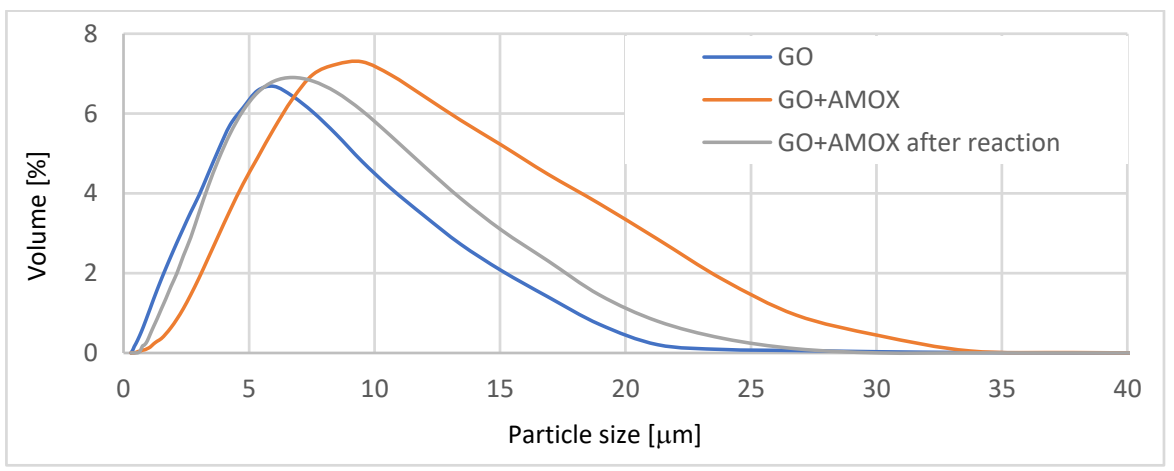

Figure 4. GO flakes size distribution.

The GO FT-IR corresponds to the images presented in the literature [42-44]. The GO spectrum as shown in Figure 3 shows a broad peak located at $3700-2500 \mathrm{~cm}^{-1}$ attributed to the stretching vibration in hydroxyl groups, signals at 1720 and $1614 \mathrm{~cm}^{-1}$ belonging to the carbonyl groups, signals at 1300 and $1210 \mathrm{~cm}^{-1}$ due to deformation vibration in $\mathrm{C}-\mathrm{OH}$, $1042 \mathrm{~cm}^{-1}$ represented by C-O groups sometimes designated to C-O-C groups, and peak at $966 \mathrm{~cm}^{-1}$ that may be assigned to the epoxy groups.

\subsection{GO-AMOX Complex Preparation}

The binding efficiencies of the peptide and AMOX were based on the mass balance of the given compound from the solutions before and after binding-Table 1. The mass of the attached peptide was $0.145 \pm 0.031 \mathrm{mg}$ per $1 \mathrm{mg}$ of GO, and the binding efficiency was close to $100 \%$ when the dose-volume was appropriately matched to the mass of GO. 
Table 1. Binding efficiency of the linker and AMOX (average values from four measurements calculated on $1 \mathrm{mg}$ of GO).

\begin{tabular}{ccccc}
\hline & Volume [mL] & $\begin{array}{c}\text { Number of Molecules } \\
\text { Administered }\end{array}$ & $\begin{array}{c}\text { Number of Molecules } \\
\text { Attached }\end{array}$ & Efficiency [\%] \\
\hline \multirow{2}{*}{ Gly-Gly-Leu } & 13 & $3.19 \times 10^{17} \pm 5.69 \times 10^{16}$ & $3.16 \times 10^{17} \pm 6.61 \times 10^{16}$ & 99.06 \\
\cline { 2 - 5 } & 26 & $6.39 \times 10^{17} \pm 9.32 \times 10^{16}$ & $3.94 \times 10^{17} \pm 8.27 \times 10^{16}$ & 61.66 \\
\hline \multirow{2}{*}{ AMOX } & 6 & $4.17 \times 10^{17} \pm 3.13 \times 10^{16}$ & $3.05 \times 10^{17} \pm 4.21 \times 10^{16}$ & 74.39 \\
\cline { 2 - 5 } & 8 & $5.56 \times 10^{17} \pm 5.51 \times 10^{16}$ & $3.14 \times 10^{17} \pm 4.78 \times 10^{16}$ & 56.47 \\
\hline
\end{tabular}

The GO flakes containing on average $3.94 \times 10^{17}$ molecules of the peptide linker were used for AMOX attachment. Independently from the AMOX solution volume, the bound mass was $0.1824 \pm 0.026 \mathrm{mg}$ per $1 \mathrm{mg} \mathrm{GO}$, which corresponds to around $3 \times 10^{17}$ molecules per $1 \mathrm{mg}$ GO. The AMOX attachment was visualized by FT-IR spectra and particles size increase-Figures 3 and 4, respectively.

\subsection{Physical Stability of GO-AMOX Alginate Capsules}

Due to the good dispersion of GO flakes using ultrasound the obtained capsules were pseudo-homogeneous (contained uniform dispersion of GO flakes)-Figure 5. Capsules' diameter was in the range of $3.735 \pm 0.224 \mathrm{~mm}$.

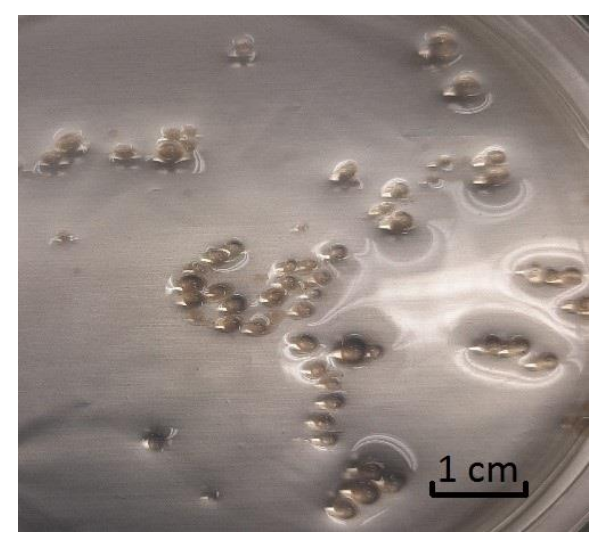

Figure 5. The image of GO-AMOX alginate capsules.

The stability of the capsules was determined based on the change of their diameter after incubation in 0.1 M MES buffer ( $\mathrm{pH}$ 6.6), in artificial saliva ( $\mathrm{pH}$ 6.8) and demineralised water ( $\mathrm{pH}$ 6.8) by 30 days. The observed changes are shown in Figure 6. Over 30 days, the capsules did not disintegrate in any of the solutions. Despite the increase in capsule diameter, GO flakes did not flow out of the capsules. Also, the significant presence of monovalent cations in the artificial saliva [45] did not adversely affect the stability of the capsules. 


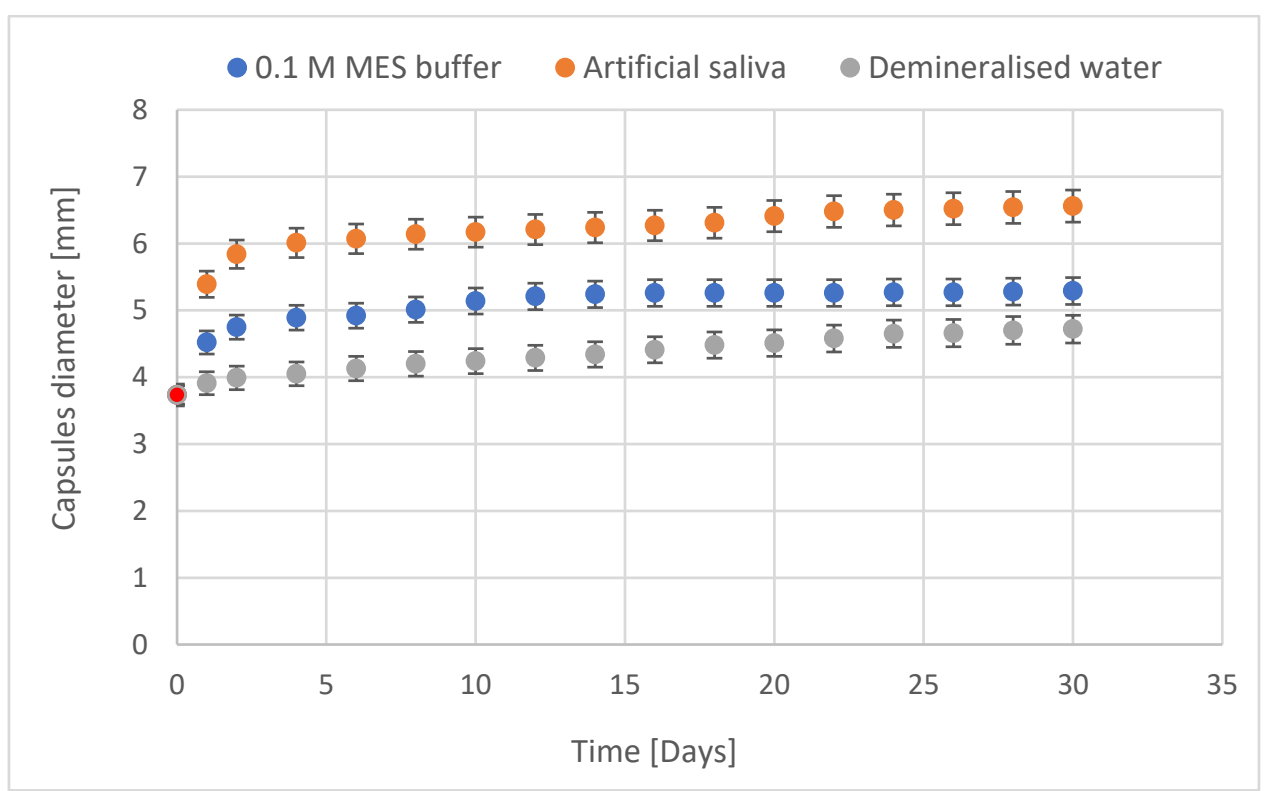

Figure 6. GO-AMOX alginate capsules stability expressed by their diameter $\left(\mathrm{T}=37^{\circ} \mathrm{C}\right)$. Initial capsules' diameter was $3.735 \pm 0.224 \mathrm{~mm}$ (a red point).

\subsection{Enzymatic Hydrolysis-Antimicrobial Properties of GO-AMOX Alginate Capsules}

$\mathrm{BROM}$, an enzyme of plant origin, was used in the study. According to the literature, the optimum activity and high stability of this enzyme occur at $\mathrm{pH} 7.0$ and a temperature of $30-37^{\circ} \mathrm{C}[46,47]$. Due to the potential use of the developed drug carrier in dentistry, the studies were conducted at $\mathrm{pH}$ 6.6, corresponding to the normal $\mathrm{pH}$ of saliva, at the human body temperature of $37^{\circ} \mathrm{C}$.

The protein linker used in the attachment of the antibiotic molecules was selected to the substrate specificity of BROM. It is the enzyme with low substrate specificity; however, from the amino acid composition of peptides obtained after BROM treatment, some preferences of BROM can be found [48]. Dominate the peptides with glycine at the $\mathrm{N}^{\prime}$ terminal while neutral amino acids (leucine, phenylalanine, alanine) at the $C^{\prime}$ terminal of peptide chains. Hence, the linker used was the Gly-Gly-Leu peptide.

Table 2 shows the effect of enzyme concentration on the release efficiency of AMOX from the carrier. A BROM solution of $0.2 \mathrm{mg} / \mathrm{mL}$ was selected to further research. More than $90 \%$ of bound AMOX molecules were released at this concentration within $24 \mathrm{~h}-$ Table 2.

Table 2. The efficiency of the AMOX releasing (average values from four measurements) with BROM encapsulated in alginate by $24 \mathrm{~h}$. The initial number of AMOX molecules attached to $1 \mathrm{mg}$ of GO was $3.14 \times 10^{17} \pm 4.78 \times 10^{16}$.

\begin{tabular}{ccc}
\hline BROM Concentration [mg/mL] & Number of AMOX Molecules Released & Efficiency [\%] \\
\hline 0.04 & $0.92 \times 10^{17} \pm 1.17 \times 10^{15}$ & 19.30 \\
\hline 0.10 & $1.95 \times 10^{17} \pm 8.61 \times 10^{15}$ & 62.10 \\
\hline 0.20 & $2.84 \times 10^{17} \pm 1.85 \times 10^{16}$ & 90.45 \\
\hline 0.40 & $3.02 \times 10^{17} \pm 2.21 \times 10^{16}$ & 96.18 \\
\hline
\end{tabular}

The antibiotic molecules released by hydrolysis contain attached leucine. The molecular weight of the released molecules was visualised by mass spectrometry (Q-Tof Mass Spectrometer, Bruker Daltonics, Billerica, MA, USA). An amino acid blocking the $\mathrm{NH}_{2}$ group, as described in the literature $[49,50]$ doesn't influence the antimicrobial properties of AMOX. 
Figure 7 compares the growth of E. faecalis cultures in the presence of alginate capsules with AMOX dissolved in the carrier and the presence of capsules including GO-AMOX and BROM at the concentration $0.2 \mathrm{mg} / \mathrm{mL}$. In both cases, inhibition of growth (zone II) was observed at the site of capsule placement. When drugs are encapsulated in an alginate network, the diffusion of drug molecules is very fast [51,52]. Hence, the effect of such capsules was obtained as expected. However, studies have shown that also molecules bound to GO prevent strain growth. This fact confirms that BROM encapsulated inside the carrier effectively releases AMOX. The exemption of AMOX from the GO was also made visible through FT-IR and particle size analysis. After $24 \mathrm{~h}$ of enzyme activity, the GO particle size is similar to that before AMOX attachment (Figure 4). In the FT-IR image, there is a visible loss of signal at $2920 \mathrm{~cm}^{-1}$, which is visible in the image for AMOX and appeared in the GO-AMOX image (Figure 3).

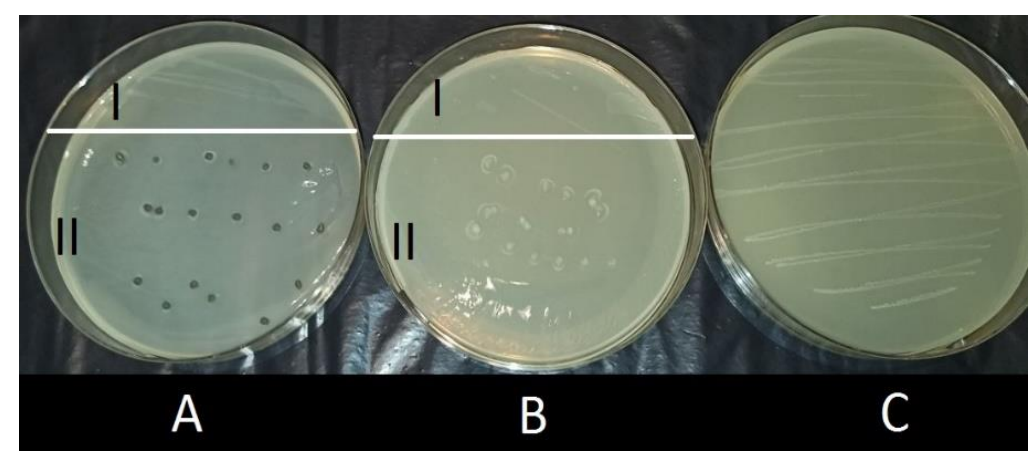

Figure 7. Effect of growth inhibition of E.faecalis by AMOX-a reduction culture $\left(37^{\circ} \mathrm{C}, 72 \mathrm{~h}\right)$. (A) GO-AMOX + BROM alginate capsules $\left(1: 2 \mathrm{mg}_{\mathrm{GO}} / \mathrm{mL}_{\text {Alginate }}, \mathrm{m}_{\mathrm{AMOX}} / \mathrm{m}_{\mathrm{GO}}=0.18, \mathrm{C}_{\mathrm{E}}=0.2\right.$ $\left.\mathrm{mg} / \mathrm{mL}_{\text {Alginate }}\right)$; (B) Alginate capsules with $\operatorname{AMOX}\left(\mathrm{C}_{\text {AMOX }}=0.09 \mathrm{mg} / \mathrm{mL}_{\text {Alginate }}\right)$; (C) Control.

\subsection{Cytotoxic Effects of Prepared Drug Carries}

Although the cytotoxic effect of GO flakes has been investigated previously [31], cytotoxicity of the prepared carriers with AMOX was determined-Figure 8.

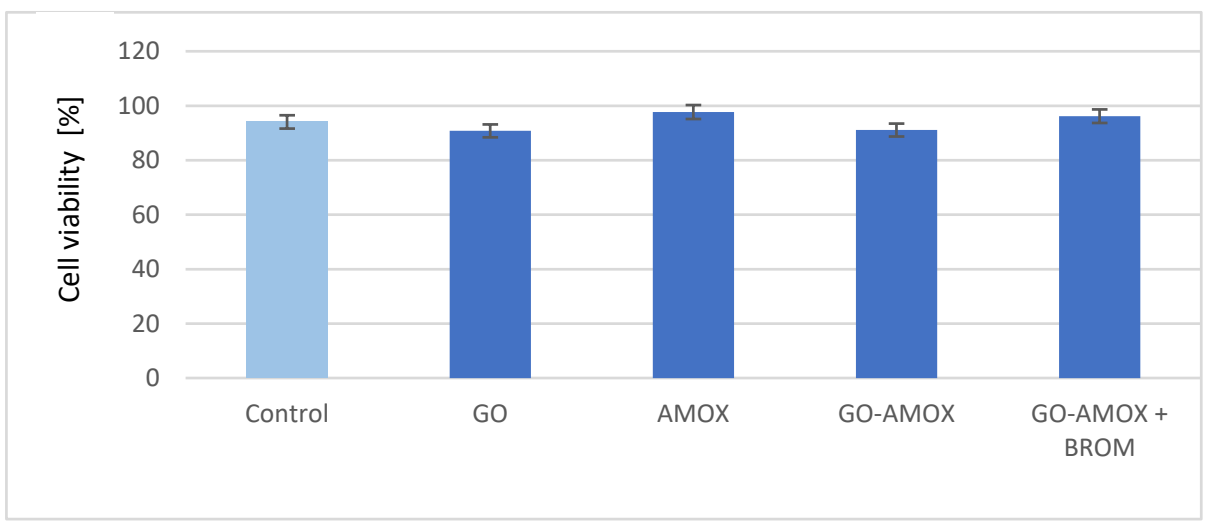

Figure 8. Mice fibrosarcoma WEHI 164 cells viability in the presence of GO $(1 \mathrm{mg} \mathrm{GO} / \mathrm{mL})$, AMOX solution $(180 \mu \mathrm{g} / \mathrm{mL})$, GO-AMOX $\left(1 \mathrm{mg}_{\mathrm{GO}} / \mathrm{mL}, \mathrm{m}_{\mathrm{AMOX}} / \mathrm{m}_{\mathrm{GO}}=0.18\right)$, GO-AMOX and the enzyme $(\mathrm{BROM})$ solution $\left(0.1 \mathrm{mg}_{\mathrm{GO}} / \mathrm{mL}, \mathrm{m}_{\mathrm{AMOX}} / \mathrm{m}_{\mathrm{GO}}=0.18, \mathrm{C}_{\mathrm{E}}=0.2 \mathrm{mg} / \mathrm{mL}\right)$. Control一the cells growth without any additions.

The cells cultured in the absence of additions served as a control served, for which a value of $94.1 \%$ of viable cells was obtained. In the presence of GO flakes and GO with bound antibiotic, the values obtained are only slightly lower ( $>90 \%$ live cells), which confirmed the lack of GO cytotoxicity. The presence of antibiotic improves a little bit of cell viability, both for AMOX solution and AMOX enzymatically released from the carrier. Such effect as for AMOX was reported in the literature for other antibiotics [53,54]. 


\section{Discussion}

In the paper of Tahriria et al. [55] about the opportunities and challenges of graphene and its derivatives in dentistry, it was presented that graphene-based materials can be used to improve characteristics of dental materials. For example, the addition of graphene or its derivatives, e.g., to resins, cement can improve their mechanical properties, increase surface area, and enhance their bioactivity. GO coating of collagen membranes promote the process of osteoblastic differentiation, and decrease inflammation [56]. Graphene nanoplates are used as a nanofiller in a commercial dental adhesive to combat bacterial growth susceptibility [57]. Following the recommendation about the local treatment of infection in dentistry [58], the new challenges in GO addition were demonstrated in this research.

The proposed kind of carriers was based on GO and hydrogel as an environmentfriendly enzymatic activity [59]. The combination of GO with hydrogels was described previously in another drug delivery context. GO-based hydrogels present functional properties, for instance, $\mathrm{pH}$-responsiveness, good mechanical properties, and thermal stabilities [60]. Thus this combination was tested, i.e., in curing bacterial infections in the gastrointestinal tract $[61,62]$.

The presented role of BROM encapsulated together with GO-AMOX complex was to hydrolyse the peptide bond between the AMOX molecule and a peptide linker (GlyGly-Leu) selected to match the substrate specificity of the enzyme. Once released from the carrier, the AMOX molecule readily diffused through the hydrogel network and could penetrate the site of action (infected area). As it was shown, the enzyme activity (concentration inside hydrogel) control the rate of drug release. From here, the dosage can be planned throughout the therapy.

For the first time, BROM was used as a catalyst applied in drug molecules release. In addition to its catalytic properties, BROM can act as a phytotherapeutic drug. Its therapeutic properties were discovered several years ago; hence the potential of this substance has not yet been fully exploited. In dentistry, BROM has been used for its anti-inflammatory action, especially after the extraction of third molars. The effect of BROM was better than that of paracetamol and similar to diclofenac and ketoprofen [63]. A recent literature review has also shown that $\mathrm{BROM}$ is effective in reducing inflammation and oedema. Minimum inhibitory con-centration of BROM was tested on isolated strains of Streptococcus mutans, Enterococcus faecalis, Aggregatibacter actinomycetemcomitans, and Porphyromonas gingivalis. S. mutans showed sensitivity at the lowest concentration of $2 \mathrm{mg} / \mathrm{mL}$, P. gingivalis at $4.15 \mathrm{mg} / \mathrm{mL}$, A. actinomycetemcomitans at $16.6 \mathrm{mg} / \mathrm{mL}$, while E. faecalis at $31.25 \mathrm{mg} / \mathrm{mL}$ [64].

Based on the obtained data and using the antibacterial properties of BROM, an ideal combination would be developing such a drug carrier in which BROM is used firstly to release drug molecules and then leave the carrier to complete the antibacterial therapy. It is a matter of selecting a suitable outer coating covering the hydrogel $[65,66]$.

\section{Conclusions}

A carrier with progressively released antibiotic molecules could replace, i.e., the paste currently used to treat periodontal abscesses. In addition to the antibiotic, the paste components are glycerol solvent, glycerol monostearate having emulsifying properties, and paste consistency and parabens, e.g., propyl para-hydroxybenzoate and methyl parahydroxybenzoate having preservative properties. These are substances that can cause severe allergies $[67,68]$.

The study showed that the enzyme encapsulated together with flake GO to which antibiotic molecules are chemically attached releases drug molecules, affecting the inhibition growth of bacteria sensitive to the antibiotic. Unlike pastes, in which the mass of the administered drug is usually used in excess, the rate of drug release is controlled by the enzyme concentration chosen. 
The procedure of carrier preparation used does not exclude the attachment of two different drugs simultaneously. Thus, our further research will focus on the co-immobilisations of two different antibiotics to which a wide range of bacterial strains will show sensitivity. In this way, universal drug carriers for periodontal and endodontic diseases treatment will be obtained.

Author Contributions: Conceptualization, A.T. and E.K.; methodology, A.T.; software, E.K.; validation, A.T. and E.K.; formal analysis, A.T. and E.K.; investigation, A.T.; resources, A.T.; data curation, E.K.; writing—original draft preparation, A.T.; writing—review and editing, E.K.; visualization, A.T. and E.K.; supervision, A.T.; project administration, A.T.; funding acquisition, A.T. and E.K. All authors have read and agreed to the published version of the manuscript.

Funding: The research carried out under the project No.2013/11/B/ST8/03672.

Institutional Review Board Statement: Not applicable.

Informed Consent Statement: Not applicable.

Data Availability Statement: The data presented in this study are available on request from the corresponding author. The data are not publicly available due the continuation of patentable research.

Conflicts of Interest: The authors declare no conflict of interest.

\section{References}

1. Liu, J.; Cui, L.; Losic, D. Graphene and graphene oxide as new nanocarriers for drug delivery applications. Acta Biomater. 2013, 9, 9243-9257. [CrossRef]

2. Wallace, P.R. The Band Theory of Graphite. Phys. Rev. 1947, 71, 622-634. [CrossRef]

3. Berger, C.; Song, Z.; Li, T.; Li, X.; Ogbazghi, A.Y.; Feng, R.; Dai, Z.; Marczenkow, A.N.; Conrad, E.H.; First, P.N.; et al. Ultrathin Epitaxial Graphite: 2D Electron Gas Properties and a Route toward Graphene-based Nanoelectronics. J. Phys. Chem. B 2004, 108, 19912-19916. [CrossRef]

4. Novoselov, K.S. Electric Field Effect in Atomically Thin Carbon Films. Science 2004, 306, 666-669. [CrossRef]

5. Zhao, M.; Shan, T.; Wu, Q.; Gu, L. The antibacterial effect of graphene oxide on Streptococcus mutans. J. Nanosci. Nanotechnol. 2019, 20, 2095-2103. [CrossRef]

6. Liu, S.; Zeng, T.H.; Hofmann, M.; Burcombe, E.; Wei, J.; Jiang, R.; Kong, J.; Chen, Y. Antibacterial activity of graphite, graphite oxide, graphene oxide, and reduced graphene oxide: Membrane and oxidative stress. ACS Nano 2011, 5, 6971-6980. [CrossRef]

7. Qiu, J.; Wang, D.; Geng, H.; Guo, J.; Qian, S.; Liu, X. How oxygen containing groups on graphene influence the antibacterial behaviors. Adv. Mater. Interfaces 2017, 4, 1700228. [CrossRef]

8. Shim, G.; Kim, M.G.; Park, J.Y.; Oh, Y.K. Graphene-based nanosheets for delivery of chemotherapeutics and biological drugs. Adv. Drug Deliv. Rev. 2016, 105, 205-227. [CrossRef] [PubMed]

9. Zhang, W.; Guo, Z.; Huang, D.; Liu, Z.; Guo, X.; Zhong, H. Synergistic effect of chemo-photothermal therapy using pegylated graphene oxide. Biomaterials 2011, 32, 8555-8561. [CrossRef]

10. Shareena, T.P.D.; Asok, D.; Dasmahapatra, K.; Tchounwou, P.B. A Review on Graphene-Based Nanomaterials in Biomedical Applications and Risks in Environment and Health. Nano-Micro Lett. 2018, 10. [CrossRef]

11. Loh, K.P.; Bao, Q.; Ang, P.K.; Yang, J. The chemistry of graphene. J. Mater. Chem. 2010, 20, 2277-2289. [CrossRef]

12. Dikin, D.A.; Stankovich, S.; Zimney, E.J; Piner, R.D.; Dommett, G.H.B.; Evmenenko, G.; Nguyen, S.T.; Ruoff, R.S. Preparation and characterization of graphene oxide paper. Nature 2007, 448, 457-460. [CrossRef]

13. Dreyer, D.R.; Park, S.; Bielawski, C.W.; Ruoff, R.S. The chemistry of graphene oxide. Chem. Soc. Rev. 2010, 39, 228-240. [CrossRef]

14. Molander, A.; Reit, C.; Dahlén, G.; Kvist, T. Microbiological status of root-filled teeth with apical periodontitis. Int. Endod. J. 1998, 31, 1-7. [CrossRef] [PubMed]

15. Sundqvist, G.; Figdor, D.; Persson, S.; Sjögren, U. Microbiologic analysis of teeth with failed endodontic treatment and the outcome of conservative re-treatment. Oral Surg. Oral Med. Oral Pathol. Oral Radiol. Endod. 1998, 85, 86-93. [CrossRef]

16. Cheung, G.S.; Ho, M.W. Microbial flora of root canal-treated teeth associated with asymptomatic periapical radiolucent lesions. Oral Microbiol. Immunol. 2001, 16, 332-337. [CrossRef]

17. Peciuliene, V.; Reynaud, A.; Balciuniene, I.; Haapasalo, M. Isolation of yeasts and enteric bacteria in root-filled teeth with chronic apical periodontitis. Int. Endod. J. 2001, 34, 429-434. [CrossRef] [PubMed]

18. Rôças, I.N.; Siqueira, J.F. F. Association of Enterococcus faecalis with different forms of periradicular diseases. J. Endod. 2004, 30, 315-320. [CrossRef]

19. Blome, B.; Braun, A.; Sobarzo, V.; Jepsen, S. Molecular identification and quantification of bacteria from endodontic infections using real-time polymerase chain reaction. Oral Microbiol. Immunol. 2008, 23, 384-390. [CrossRef] [PubMed]

20. Rôças, I.N.; Siqueira, J.F.J. Characterization of microbiota of root canal-treated teeth with posttreatment disease. J. Clin. Microbiol. 2012, 50, 1721-1724. [CrossRef] [PubMed] 
21. Chow, A.T.; Quah, S.Y.; Bergenholtz, G.; Lim, K.C.; Yu, V.S.H.; Tan, K.S. Bacterial species associated with persistent apical periodontitis exert differential effects on osteogenic differentiation. Int. Endod. J. 2019, 52, 201-210. [CrossRef]

22. Pereira, C.V.; Stipp, R.N.; Fonseca, D.C.; Pereira, L.J.; Höfling, J.F. Detection and Clonal Analysis of Anaerobic Bacteria Associated to Endodontic-Periodontal Lesions. J. Periodontol. 2011, 82, 1767-1775. [CrossRef]

23. Martinho, F.C.; Leite, F.R.M.; Nascimento, G.G.; Cirelli, J.A.; Gomes, B.P.F.A. Clinical investigation of bacterial species and endotoxinin endodontic infection and evaluation of root canal contentactivity against macrophages by cytokine production. Clin. Oral Investig. 2014, 18, 2095-2102. [CrossRef]

24. He, J.; Zhu, X.; Qi, Z.; Wang, L.; Aldalbahi, A.; Shi, J.; Song, S.; Fan, C.; Lv, M.; Tang, Z. The inhibition effect of graphene oxide nanosheets on the development of Streptococcus mutans biofilms. Part. Syst. Charact. 2017, 34, 1700001. [CrossRef]

25. He, J.; Zhu, X.; Qi, Z.; Wang, C.; Mao, X.; Zhu, C.; He, Z.; Li, M.; Tang, Z. Killing Dental Pathogens Using Antibacterial Graphene Oxide. ACS Appl. Mater. 2015, 7, 5605-5611. [CrossRef]

26. Ge, Z.; Yang, L.; Xiao, F.; Wu, Y.; Yu, T.; Chen, J.; Lin, J.; Zhang, Y. Graphene family nanomaterials: Properties and potential applications in dentistry. Int. J. Biomater. 2018, 1-11. [CrossRef]

27. Xie, H.; Cao, T.; Rodríguez-Lozano, F.J.; Luong-Van, E.K.; Rosa, V. Graphene for the development of the next-generation of biocomposites for dental and medical applications. Dent. Mater. 2017, 33, 765-774. [CrossRef]

28. Corrêa, J.M.; Mori, M.; Sanches, H.L.; Cruz, A.D.; Poiate, E.; Poiate, I.A.V.P. Silver nanoparticles in dental biomaterials. Int. J. Biomater. 2015, 1-9. [CrossRef]

29. Qian, W.; Qiu, J.; Su, J.; Liu, X. Minocycline hydrochloride loaded on titanium by graphene oxide: An excellent antibacterial platform with the synergistic effect of contact-killing and release-killing. Biomater. Sci. 2018, 6, 304-313. [CrossRef] [PubMed]

30. Upadhyay, S.K.; Dan, S.; Pant, M.; Shaloo. Synergistic Approach of Graphene Oxide-Silver-Titanium Nanocomposite Film in Oral and Dental Studies: A New Paradigm of Infection Control in Dentistry. Biointerface Res. Appl. Chem. 2020, 11, 9680-9703. [CrossRef]

31. Trusek, A.; Kijak, E.; Granicka, L. Graphene oxide as a potential drug carrier-Chemical carrier activation, drug attachment and its enzymatic controlled release. Mater. Sci. Eng. C 2020, 116, 111240. [CrossRef] [PubMed]

32. Arican, B.; Ciftcioglu, E.; Isik, V.; Karagoz-Kucukay, I. Evaluation of the knowledge of final-year dental students on the use of antibiotics in endodontics in Turkey. Aust. Endod. J. 2021. [CrossRef]

33. Trusek, A. Graphene oxide flake activation via divinylsulfone-A procedure for efficient $\beta$-galactosidase immobilization. Pol. J. Chem. Technol. 2019, 21, 27-32. [CrossRef]

34. Yu, A.; Shang, J.; Cheng, F.; Paik, B.A.; Kaplan, J.M.; Andrade, R.B.; Ratner, D.M. Biofunctional Paper via the Covalent Modification of Cellulose. Langmuir 2012, 28, 11265-11273. [CrossRef] [PubMed]

35. Nishimura, T.; Toh, W.L.; Akiyoshi, K. Synthesis and Characterization of Shell-Cross-Linked Glycopolymer Bilayer Vesicles. Macromol. Rapid Commun. 2018, 39. [CrossRef]

36. Tian, L.J.; Singh, A.; Singh, A.V. Synthesis and characterization of pectin-chitosan conjugate for biomedical application. Intern. J. Biol. Macromol. 2020, 153, 533-538. [CrossRef]

37. Parsamehr, P.S.; Zahed, M.; Tofighy, M.A.; Mohammadi, T.; Rezakazemi, M. Preparation of novel cross-linked graphene oxide membrane for desalination applications using (EDC and NHS)-activated graphene oxide and PEI. Desalination 2019, $468,114079$. [CrossRef]

38. Trusek, A.; Dworakowska, D.; Czyżewska, K. 3D enzymatic preparations with graphene oxide flakes and hydrogel to obtain lactose-free products. Food Bioprod. Process. 2020, 121, 224-229. [CrossRef]

39. Caviglia, C.; Zor, K.; Montini, L.; Tilli, V.; Canepa, S.; Melander, F.; Muhammad, H.B.; Carminati, M.; Ferari, G.; Raiteri, R.; et al. Impedimetric toxicity assay in microfluidics using free and liposome-encapsulated anticancer drugs. Anal. Chem. 2015, 87, 2204-2212. [CrossRef]

40. Wójcik, M.; Lewandowski, W.; Krol, M.; Pawlowski, K.; Mieczkowski, J.; Lechowski, R.; Zabielska, K. Enhancing anti-tumor efficacy of doxorubicin by non-covalent conjugation to gold nanoparticles-In vitro studies on feline fibroscona cell lines. PLoS ONE 2015, 10, e0124955. [CrossRef]

41. Graphene Flakes in Water Solution, 1\% (Flake Size). Available online: https://advancedgrapheneproducts.com/en/produkt/ graphene-flakes-in-water-solution-1-flake-size-20-\%ce\%bcm/?wmc-currency=EUR (accessed on 11 July 2020).

42. Ciszewski, M.; Mianowski, A.; Szatkowski, P.; Nawrat, G.; Adamek, J. Reduced graphene oxide-bismuth oxide composite as electrode material for supercapacitors. Ionics 2015, 21, 557-563. [CrossRef]

43. Andrijanto, E.; Shoelarta, S.; Subiyanto, G.; Rifki, S. Facile synthesis of graphene from graphite using ascorbic acid as reducing agent. AIP Conf. Proc. 2016, 1725, 020003. [CrossRef]

44. Lee, D.W.; De Los Santos, V.L.; Seo, J.W.; Leon Felix, L.; Bustamante, D.A.; Cole, J.M.; Barnes, C.H.W. The Structure of Graphite Oxide: Investigation of Its Surface Chemical Groups. J. Phys. Chem. B 2010, 114, 5723-5728. [CrossRef] [PubMed]

45. Pytko-Polonczyk, J.; Jakubik, A.; Pieklasa-Bierowiec, A.; Muszynska, B. Artifial saliva and its use in biological experiments. J. Physiol. Pharmacol. 2017, 68, 807-813.

46. Nurhidayat, I.; Satiasih, S.; Handayani, S.; Hudiyono, S. Kinetic Studies of Bromelain Purified from Palembang Pineapple (Ananas comosus [L.] Merr) Using Gel Filtration Chromatography and Its Activity as Antiplatelet Aggregation. In Proceedings of the 3rd International. Symposium on Current Progress in Mathematics and Sciences, Bali, Indonesia, 26-27 July 2017; Volume 2023, p. 020068. [CrossRef] 
47. Silvestre, M.P.C.; Carreira, R.L.; Silva, M.R.; Corgosinho, F.C.; Monteiro, M.R.P.; Morais, H.A. Effect of pH and Temperature on the Activity of Enzymatic Extracts from Pineapple Peel. Food Bioproc. Technol. 2012, 5, 1824-1831. [CrossRef]

48. Chandrasekaran, S.; Luna-Vitaland, D.; Gonzalez de Mejia, E. Identification and Comparison of Peptides from Chickpea Protein Hydrolysates Using Either Bromelain or Gastrointestinal Enzymes and Their Relationship with Markers of Type 2 Diabetesand Bitterness. Nutrients 2020, 12, 3843. [CrossRef] [PubMed]

49. Davis, B.G.; Robinson, M.A. Drug delivery systems based on sugar-macromolecule conjugates. Curr. Opin. Drug Discov. Dev. 2002, 5, 279-288.

50. Grumezescu, A.M. Nano- and Microscale Drug Delivery Systems: Design and Fabrication; Elsevier: Amsterdam, The Netherlands, 2017.

51. Trusek-Holownia, A.; Jaworska, P. Polymeric drug carriers-Control of the daily dose and therapy duration. Biocybern. Biomed. Eng. 2015, 35, 192-197. [CrossRef]

52. Grassi, M.; Grassi, G. Mathematical Modelling and Controlled Drug Delivery: Matrix Systems. Curr. Drug Deliv. $2005,2$. [CrossRef] [PubMed]

53. Rathbone, C.R.; Cross, J.D.; Brown, K.V.; Murray, C.K.; Wenke, J.C. Effect of various concentrations of antibiotics on osteogenic cell viability and activity. J. Orthop. Res. 2011, 29, 1070-1074. [CrossRef]

54. Parker, R.A.; Clegg, P.D.; Taylor, S.E. The in vitro effects of antibiotics on cell viability and gene expression of equine bone marrow-derived mesenchymal stromal cells. Equine Vet. J. 2012, 44, 355-360. [CrossRef]

55. Tahriria, M.; Del Monicoa, M.; Moghanian, A.; Tavakkoli Yarakic, M.; Torresa, R.; Yadegaria, A.; Tayebia, L. Graphene and its derivatives: Opportunities and challenges in dentistry. Mater. Sci. Eng. C Mater. Biol. Appl. 2019, 102, 171-185. [CrossRef] [PubMed]

56. Radunovic, M.; De Colli, M.; De Marco, P.; Di Nisio, C.; Fontana, A.; Piattelli, A.; Cataldi, A.; Zara, S. Graphene oxide enrichment of collagen membranes improves DPSCs differentiation and controls inflammation occurrence. J. Biomed. Mater. Res. A 2017, 105, 2312-2320. [CrossRef]

57. Bregnocchi, A.; Zanni, E.; Uccelletti, D.; Marra, F.; Cavallini, D.; De Angelis, F.; De Bellis, G.; Bossu, M.; Ierardo, G.; Polimeni, A.; et al. Graphene-based dental adhesive with anti-biofilm activity. J. Nanobiotechnol. 2017, 15, 89. [CrossRef]

58. Goldberg, M. Antibiotics and Antibacterial Medications for Endodontic Treatments. JSM Dent. 2020, 8, 1124.

59. Labus, K.; Drozd, A.; Trusek-Holownia, A. Preparation and characterisation of gelatine hydrogels predisposed to use as matrices for effective immobilisation of biocatalysts. Chem. Pap. 2016, 70, 523-530. [CrossRef]

60. Song, F.; Hu, W.; Xiao, L.; Cao, Z.; Li, X.; Zhang, C.; Liao, L.; Liu, L. Enzymatically cross-linked hyaluronic acid/graphene oxide nanocomposite hydrogel with pH-responsive release. J. Biomater. Sci. Polym. Ed. 2015, 26, 339-352. [CrossRef] [PubMed]

61. Sengupta, I.; Kumar, S.S.S.S.; Gupta, K.; Chakraborty, S. In-vitro release study through novel graphene oxide aided alginate based $\mathrm{pH}$-sensitive drug carrier for gastrointestinal tract. Mater. Today Commun. 2021, 26, 101737. Available online: https: // scholar.google.com/citations?user=tz4a9ToAAAAJ\&hl=en (accessed on 20 April 2021). [CrossRef]

62. Hou, L.; Shi, Y.; Jiang, G.; Liu, W.; Han, H.; Feng, Q.; Ren, J.; Yuan, Y.; Wang, Y.; Shi, J.; et al. Smart nanocomposite hydrogels based on azo crosslinked graphene oxide for oral colon-specific drug delivery. Nanotechnology 2016, 27, 315105. [CrossRef]

63. Mameli, A.; Valentino, N.; Cinzia, C. Bromelain: An Overview of Applications in Medicine and Dentistry. Biointerface Res. Appl. Chem. 2021, 11, 8165-8170. [CrossRef]

64. Praveen, N.C.; Rajesh, A.; Madan, M.; Chaurasia, V.R.; Hiremath, N.V.; Sharma, A.M. In vitro Evaluation of Antibacterial Efficacy of Pineapple Extract (Bromelain) on Periodontal Pathogens. J. Int. Oral Health 2014, 6, 96-98. [PubMed]

65. Devulappy, R.; Paulmurugan, R. Polymer nanoparticles for drug and small silencing RNA delivery to treat cancers of different phenotypes. Wiley Intersiscip. Rev. Nanomed. Nanobiotechnol. 2014, 6. [CrossRef]

66. Rashid, N.M.; Kaur, V.; Hallan, S.S.; Sharma, S.; Mishra, N. Microparticles as controlled drug delivery carrier for the treatment of ulcerative colitis: A brief review. Saudi Pharm. J. 2016, 24, 458-472. [CrossRef]

67. Shimizu, Y.; Kambayashi, Y.; Tsujiguchi, H.; Hara, A.; Hori, D.; Nguyen, T.T.T.; Suzuki, F.; Hamagishi, T.; Yamada, Y.; Nakamura, H.; et al. Relationship between the Use of Parabens and Allergic Diseases in Japanese Adults-A Cross-Sectional Study. J-Multidiscip. Sci. J. 2018, 1, 148-158. [CrossRef]

68. Nan, A. Miscellaneous Drugs, Materials, Medical Devices and Techniques, Ch. 47. In Side Effects of Drugs Annual; Sid Ray, S., Ed.; Elsevier: Amsterdam, The Netherlands, 2015; Volume 37. 